\title{
THE EVALUATION OF THERMAL COMFORT AFFECTED BY CONDUCTION FROM WATER HEATED FLOOR TO CONTACTED BODY SURFACE
}

\author{
熱伝導を考慮した床暖房の快適性評価に関する研究 \\ Ju-Youn LEE*, Norio ISODA**, Hiroko KUBO*** \\ and Takuko YANASE**** \\ 李 周 妍, 磯田憲生, 久保博子, 梁 瀬度子
}

\begin{abstract}
The purpose of this paper is to clarify the effect of air temperature and floor temperature on the occupants' comfort sensation in the hot water floor heating system. This paper also considers the contact areas between floor and human body to quantitatively determine the heat conduction between the floor and the subjects. The present study deals with the effect of heat conduction with regard to modified mean skin temperature. The subjects ( 7 female college students) were exposed to the following conditions : combinations of air temperatures $\left(18^{\circ} \mathrm{C}, 23^{\circ} \mathrm{C}\right)$ and water temperatures $\left(25^{\circ} \mathrm{C}, 30^{\circ} \mathrm{C}, 35^{\circ} \mathrm{C}, 40^{\circ} \mathrm{C}, 45^{\circ} \mathrm{C}\right)$ in still air and $\mathrm{RH} 40 \%$. The subjects were exposed to these conditions while sitting on the floor, sitting on a chair and lying on the floor. The following results were obtained: The skin temperature of the body parts in contact with the floor was affected by the floor temperature. The thermal sensation vote was neutral at a mean skin temperature of $33{ }^{\circ} \mathrm{C}$. Levels of thermal comfort and acceptability of the floor temperature was rated as 'satisfactory' at globe temperatures above $20^{\circ} \mathrm{C}$. The permissable comfort level of the floor temperature was found to be approximately $25^{\circ} \mathrm{C}$ at globe temperature $20^{\circ} \mathrm{C}$. New weighting coefficients to calculate mean skin temperature are derived on the basis of Hardy \& DuBois formula.
\end{abstract}

Keywords: floor heating system, heat conduction, thermal sensation, modified mean skin temperature 朱暖房、熱伝導、温冷感、伝導修正平均皮阔温

\section{INTRODUCTION}

Floor heating system has a significant influence on the mean radiant temperature in a space. It is regarded as an economical and comfortable heating system because of the radiant heat. Reasons like free use of space, no cleaning, no noise, no draft, no ducts, uniform temperature distribution and a low temperature heating system have made many people choose floor heating.(4)

Several studies have proved the comfort of floor heating system. [ASHRAE55,(1981); ISO-7730(1984); Nevins,(1964,1966); Olesen, B.W. (1977,1997); Kim,(1990); Choi,(1996) etc. ](1-8)Although a large number of studies have been made on floor heating system during winter conditions, only few studies have so far been made with different postures of the exposed subjects

The purpose of this paper is to consider the effects of air and floor temperature upon the human body, at different body postures. Even more important is to clarify the effect on parts of the body(i.e. scapula, lower back, posterior thigh, calf, and buttocks ) in contact with air temperature and floor temperature using the water based floor heating system. The paper also considers the area of contact between the floor and the human body to quantitatively determine the heat conduction between the floor and a subject. The present study will deal with the effect of heat conduction mean skin temperature(MSTd) by the floor heating system. In addition, the present paper recommends the permissible comfort range of air and floor temperature for the human body.

\section{METHOD}

\subsection{EXPERIMENTAL FACILITIES}

The experiment was carried out using a floor heating system $(\mathrm{W} 3.7 \mathrm{~m} \times$ $\mathrm{D} 3.55 \mathrm{~m})$ in climate chambers $\mathrm{A}(\mathrm{W} 4.5 \mathrm{~m} \times 5 \mathrm{~m}, \mathrm{H} 2.5 \mathrm{~m})$ and $\mathrm{B}(\mathrm{W} 3 \mathrm{~m} \times$ $\mathrm{D} 3 \mathrm{~m}, \mathrm{H} 2.5 \mathrm{~m})$ at Nara Women's University. Fig. 1 shows the plan of the climate chamber. The floor heating system was installed in the floor panels (thickness $12 \mathrm{~mm}$ ). A $7 \mathrm{~mm}$ pipe was inserted into the panels, which were $7.5 \mathrm{~cm}$ wide. Hot water was circulating through the pipes.

\section{2 EXPERIMENTAL CONDITIONS}

The subjects ( 7 female college students) were exposed to the following conditions: combinations of air temperatures $\left(\mathrm{Ta}=18 \mathrm{C}, 23^{\circ} \mathrm{C}\right)$ and water temperatures $\left(\mathrm{Tw}=25^{\circ} \mathrm{C}, 30^{\circ} \mathrm{C}, 35^{\circ} \mathrm{C}, 40^{\circ} \mathrm{C}, 45^{\circ} \mathrm{C}\right)$ air velocity less than $0.1 \mathrm{~m} / \mathrm{s}$ and relative humidity $40 \%$. In the case of air temperature at $18^{\circ} \mathrm{C}$, water temperature at $30^{\circ} \mathrm{C}$ (floor temperature $=22.5^{\circ} \mathrm{C}$ ), $35^{\circ} \mathrm{C}\left(24.3^{\circ} \mathrm{C}\right.$ ), $40^{\circ} \mathrm{C}$ $\left(26.3^{\circ} \mathrm{C}\right), 45^{\circ} \mathrm{C}\left(28.2^{\circ} \mathrm{C}\right)$ and in the case of air temperature at $23^{\circ} \mathrm{C}$, water temperature at $25^{\circ} \mathrm{C}\left(\mathrm{Tf}=23.7^{\circ} \mathrm{C}\right) 30^{\circ} \mathrm{C}\left(25.6^{\circ} \mathrm{C}\right), 35^{\circ} \mathrm{C}\left(27.5^{\circ} \mathrm{C}\right), 40^{\circ} \mathrm{C}\left(29.4^{\circ} \mathrm{C}\right)$.

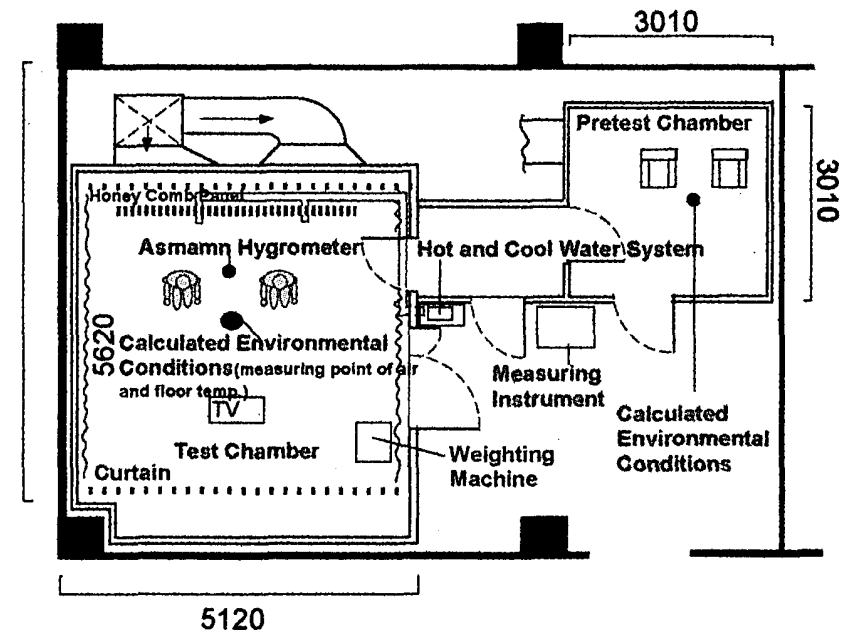

Fig.1 Plan of the Climate Chamber
* Graduate Student, Graduate School of Human Culture, Nara Women's University, MSc Home Ec.

** Prof., Graduate School of Human Culture, Nara Women's University, Dr. Eng.

*** Assoc. Prof., Faculty of Human Life and Environment, Nara Women's University, Dr. Pil.

**** Prof., School of Human Environmental Science, Mukogawa Women's University, Dr. Med.
奈良女子大学大学院人間文化研究科 博士後期課程 - 家修

奈良女子大学大学院人間文化研究科 教授. 工博 奈良女子大学生活環境学部人間環境学科 助教授・学博

武庫川女子大学生活環境学部生活環境学科 教授・医博 
The maximum vertical temperature difference was $1.4^{\circ} \mathrm{C}(\mathrm{Ta} 1.1 \mathrm{~m}-0.1 \mathrm{~m})$ when $\mathrm{Ta} 18^{\circ} \mathrm{C}$ and $\mathrm{Tw} 45^{\circ} \mathrm{C}$ and below $0.5^{\circ} \mathrm{C}$ when $\mathrm{Ta} 23^{\circ} \mathrm{C}$. Table 1 shows the experimenttal conditions.

2.3 PMYSIGAL GONDUTON AMD CMARACTERISTC OF SURBECTS

The subjects were exposed to the above conditions while sitting on the floor, sitting on a chair and lying on the floor. Fig. 2 shows the different postures to which the subjects were exposed. The subjects, who were all female were clothed in winter attire including: long sleeve shirts, sweat shirt, sweat trousers, socks and their own panties and brassieres. Table 2 shows physical condition and characteristics of subjects.

3.6. TUE MUEASURERIENT OF FLOOR CONTACT ARRA

The floor area and contact areas were measured by Miyamoto on a transparent acryl board $(2000 \mathrm{~mm} \times 1000 \mathrm{~mm} \times 25 \mathrm{~mm})$ by $1 \mathrm{~mm}$ tape fixed in a $100 \mathrm{~mm}$ lattice. (15) The subjects were positioned on the board, and pictureswere taken from the other side of the board. A $100 \mathrm{~mm}$ lattice was used to calculate the contact area through the photographs, for which the error was found to be less than $0.1 \%$. One position took less than 15 seconds to measure. Two young college females subjects were measured by a subcutaneous fat measuring instrument. The subjects were exposed to the above conditions while sitting on the floor, sitting on a chair and lying on the floor. Figure 2 shows the different postures to which the subjects were exposed. The subjects, who were all female were clothed in winter attire including: long sleeve shirts, training shirt training trousers, socks and their own panties and brassieres. The present study considered a clothing suit which adheres closely to the body. In this way the contact area is more clear than with other attires. Table 3 shows the characteristics of subjects used in the contact area measurements.

\subsection{MEASUREROENTS}

Air temperature was measured at the center of the experimental room at three different levels $(H=0.1,0.6,1.1 \mathrm{~m})$, and Globe Temperature ( $\mathrm{Tg}=$-in contact with the floor, and at $0.6 \mathrm{~m}$ ) was measured by a $15 \mathrm{~cm}$ diameter globe thermometer. Floor surface temperature was measured by a thermocouple of diameter $0.1 \mathrm{~mm} \phi$. Humidity was measured by an automatic assmann hygrometer. To determine physiological effects, the skin temperatures at 14 points were measured every 5 seconds by thermocouples $(0.1 \mathrm{~mm} \phi)$. Skin temperature was measured by a 30 point hybrid recorder and $0.1 \mathrm{~mm} \phi$ thermocouple. The rectal temperature was measured by a 30 point hybrid recorder of which the sensor was inserted about $10 \mathrm{~cm}$ into the anus of the subject. Body weight were obtained by weighting the subjects immediately before and after the experiment. The blood pressure and heart rate were obtained immediately before and after the experiment. The body surface area was calculated by Hardy \& DuBois equation and Kurazumi's equation adjusted for the shape of Japanese body.(13) Mean skin temperature was calculated by the weighted mean formula at 12 point surface area by Hardy \& DuBois.(9) The mean skin temperature was also calculated by Modified formula, which considers the effect of the parts of the body in contact with the floor. Table 5 shows the weighting coefficients for the calculation of mean skin temperature and modified mean skin temperature from this experiment.

From 30 minutes before the experiment to 60 minutes after, the subjective psychological evaluation of the whole body and local body of subjects were described at 10 minute intervals based on the traditional nine-point scale for thermal sensation votes [ -4 : very cold through +4 very hot] , and seven-point scale for thermal comfort votes [ -3 : very uncomfortable through +3 : very comfortable]. Table 4 shows the time schedule of the experiment. The experiment was done between February and March 1997.

\section{RESURTS}

\subsection{SKNO TERAPERTURE ANO RECTAL TERAPERATURE}

The following results were obtained; Fig. 3 shows the changes in skin temperature with different exposures of air and water temperature.

Generally, skin temperature of the trunk gradually increased as the environmental temperature increased. The skin temperature of peripheral parts of hands and feet had a wide range, and in the case of low environmental temperatures, the skin temperature dramatically dropped toa lower temperature. The skin temperatures of parts of the body in contact with the floor continued to rise. In the case of sitting on a chair, posterior at thigh showed higher temperature due to the contact with the chair, and except peripheral parts of the hand, temperatures instep, and soles of the feet decreased. Skin temperatures at the forearm and the back of the hand decreased and skin temperatures of thigh(p.), calf, buttock increased by sitting on the floor.

In the case of lying on the floor, body temperature was significantly affected by the floor temperature. In particular, the skin temperature of parts of the body in contact with the floor was affected by the floor temperature, for example, the scapula, lower back, thigh(p.), calf and
Table I Emperimental Conobions

\begin{tabular}{|c|c|c|c|c|c|c|}
\hline $\begin{array}{l}\text { Environmental } \\
\text { Conditions }\end{array}$ & $\begin{array}{c}\text { Air } \\
\text { remp. } \\
\text { (C) }\end{array}$ & $\begin{array}{l}\text { Orater } \\
\text { Yemp. } \\
\text { (C) }\end{array}$ & $\begin{array}{l}\text { Floor } \\
\text { Temo. } \\
\text { (C) }\end{array}$ & $\begin{array}{l}\text { Globe } \\
\text { Yemp. } \\
\text { (C) }\end{array}$ & $\begin{array}{c}\text { Relative } \\
\text { Mumidiîy } \\
(\%)\end{array}$ & $\begin{array}{c}\text { Air } \\
\text { Velocity } \\
(\mathrm{m} / \mathrm{s})\end{array}$ \\
\hline \multirow{8}{*}{$\begin{array}{l}\text { Environmental } \\
\text { Conditions } \\
\text { (Pretest Room } \\
\text { Tas23 C, } \\
\text { RH } 560 \% \text { ) }\end{array}$} & \multirow{4}{*}{$48^{\circ} \mathrm{C}$} & $30^{\circ} \mathrm{C}$ & $22.6^{\circ} \mathrm{C}$ & $19.2^{\circ} \mathrm{C}$ & \multirow{8}{*}{$\Delta 0 \%$} & \multirow{8}{*}{$\begin{array}{c}\text { less than } \\
0.1\end{array}$} \\
\hline & & $35^{\circ} \mathrm{C}$ & $26.3^{\circ} \mathrm{C}$ & $19.7^{\circ} \mathrm{C}$ & & \\
\hline & & $80^{\circ} \mathrm{C}$ & $26.3^{\circ} \mathrm{C}$ & $20.2^{\circ} \mathrm{C}$ & & \\
\hline & & $\triangle 5^{\circ} \mathrm{C}$ & $28.2^{\circ} \mathrm{C}$ & $20.7^{\circ} \mathrm{C}$ & & \\
\hline & \multirow{4}{*}{$23^{\circ} \mathrm{C}$} & $25 \mathrm{C}$ & $23.7^{\circ} \mathrm{C}$ & $23.1^{\circ} \mathrm{C}$ & & \\
\hline & & $30^{\circ} \mathrm{C}$ & $25.6^{\circ} \mathrm{C}$ & $23.6^{\circ} \mathrm{C}$ & & \\
\hline & & $35^{\circ} \mathrm{C}$ & $27.5 \mathrm{C}$ & $24.1^{\circ} \mathrm{C}$ & & \\
\hline & & $80^{\circ} \mathrm{C}$ & $29.0^{\circ} \mathrm{C}$ & $24.6^{\circ} \mathrm{C}$ & & \\
\hline
\end{tabular}

Tabre \& Physical Condion Charasteristics of SubjeGts

\section{Activity Sendentary}

Clothing $0.92 \mathrm{clo}$

\begin{tabular}{|c|c|c|c|c|c|c|}
\hline 7 Female & Agofyr.) & Heigh (4cm) & Weighakg) & 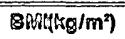 & As(min) & $A \Omega\left(m^{2}\right)^{\circ}$ \\
\hline AVO & 21.5 & 156.3 & 58 & 22.1 & 4.58 & 8.52 \\
\hline STD & \pm 0.83 & \pm 2.88 & \pm 6.66 & \pm 4.33 & \pm 0.09 & \pm 0.80 \\
\hline
\end{tabular}

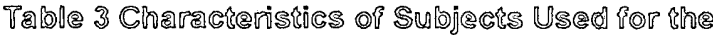
Coniceis Ares Weasurements

\begin{tabular}{|c|c|c|c|c|c|c|}
\hline 2 Female & Agq(yr.) & Height(cm) & (Weight(kg) & (Ball(kg/m²) & $A S\left(m^{2}\right)^{\circ}$ & $A \subset\left(m^{2}\right)^{\infty}$ \\
\hline AVG & $2 B$ & 160 & $\infty$ & 20.69 & 1.65 & 8.68 \\
\hline sro & $\pm \$ 2 \theta$ & \pm 7.07 & $\pm 0.2 B$ & \pm 0.17 & \pm 0.69 & \pm 0.10 \\
\hline
\end{tabular}

$A$ ( $\left.m^{2}\right)^{\circ}=$ Kurazumi's formula

As $\mathrm{m}^{2}$ ) Mardy \& Du(Sois's formula

Table \& Time Schedule of Exporiment

\begin{tabular}{|c|c|c|c|c|c|c|c|c|c|c|c|c|}
\hline Time & min & & Omir & & & $30 \mathrm{r}$ & $\min$ & & $60 \mathrm{~m}$ & & & Omin \\
\hline \multirow[t]{2}{*}{ Situation } & \multirow{2}{*}{\multicolumn{3}{|c|}{$\begin{array}{l}\text { Pre-iest room } \\
\text { Recess }\end{array}$}} & \multicolumn{7}{|c|}{$\begin{array}{l}\text { Tesi Room } \\
\text { Exposure }\end{array}$} & & \\
\hline & & & & \multicolumn{6}{|c|}{$\begin{array}{l}\infty \text { siting on the floor or } \Rightarrow \\
\text { sitiing on a chalr }\end{array}$} & \multicolumn{3}{|c|}{$\begin{array}{l}\text { क lying on the floort } \\
\text { afier sikting on a chalr }\end{array}$} \\
\hline \multicolumn{5}{|c|}{ Skin Temp. } & \multicolumn{8}{|c|}{ inierval 30second } \\
\hline Weight los & & & & $\nabla$ & & & & & & $\nabla \nabla$ & & $\nabla$ \\
\hline Vores & $\nabla$ & $\nabla$ & $\nabla$ & $\nabla$ & $\nabla$ & $\nabla$ & $\nabla$ & $\nabla$ & $\nabla$ & $\nabla \nabla$ & $\nabla$ & $\nabla$ \\
\hline
\end{tabular}

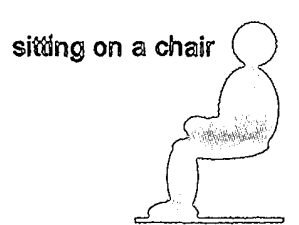

sixting on the fioor

lying on the floor

\section{noor}

Fig. 2 The Dirrerent Positions ro Which the Subjects vere [mposed

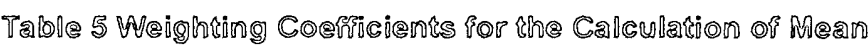
Skin Temperainre Ascording so Manty-DuBois

\begin{tabular}{|c|c|c|c|c|c|c|c|}
\hline \multirow{3}{*}{$\begin{array}{l}\text { Measuring } \\
\text { Position }\end{array}$} & \multirow{3}{*}{$\begin{array}{l}\text { Mardy - } \\
\text { Dusois }\end{array}$} & \multicolumn{6}{|c|}{ Alodified Weighuing Facrors } \\
\hline & & \multicolumn{2}{|c|}{ sixing on a chair } & \multicolumn{2}{|c|}{ sixing on the foor } & \multicolumn{2}{|c|}{ Iying on the noor } \\
\hline & & uncontace & contact & unconiaci & comiaci & uncontact & coniact \\
\hline foreheas & 0.07 & 0.07 & & 0.07 & & 0.07 & \\
\hline upper chest & 0.0875 & 0.0875 & & 0.0875 & & $0.1603(A)$ & \\
\hline scapula & 0.0875 & 0.0875 & & 0.0875 & & & $0.0147(\mathrm{~A} 1)$ \\
\hline abolomen & 0.0875 & 0.0875 & & 0.0875 & & 0.0875 & \\
\hline lower back & 0.0875 & 0.0875 & & 0.0875 & & 0.0875 & \\
\hline forearn & 0.14 & 0.14 & & 0.14 & & 0.14 & \\
\hline orck of hand & 0.05 & 0.05 & & 0.05 & & 0.05 & \\
\hline thigha.) & 0.095 & 0.085 & & 0.0950 & & $0.1495(B)$ & \\
\hline thighto.) & 0.095 & 0.095 & & 0.0798 & & & $0.0071(B 1)$ \\
\hline shin & 0.035 & 0.055 & & 0.085 & & $0.1185(C)$ & \\
\hline calis & 0.085 & 0.055 & & 0.065 & & & 0.0115 (Ci) \\
\hline instep & 0.07 & 0.0816 & & 0.0607 & & $0.0888(D)$ & \\
\hline bustock & & & & & 0.0152 & & $0.0334(B 2)$ \\
\hline sols & & & 0.0084 & & 0.0093 & & \\
\hline hed & & & & & & & $0.0011(\mathrm{D} 1)$ \\
\hline Polal & 1 & sera & & 1 & & & 1 \\
\hline
\end{tabular}


buttock. In the case of water temperature at $45^{\circ} \mathrm{C}$, a marked increase in temperatures were observed at the buttock and the scapula, to about $36^{\circ} \mathrm{C}$ The skin temperature of the soles of the feet when lying decreased compared with sitting on the floor and sitting on a chair. The mean skin temperature ranged from $31.3^{\circ} \mathrm{C}$ to $33.8^{\circ} \mathrm{C}$. The modified mean skin temperature was valued higher than the mean skin temperature in the same manner as Choi's result in the case of sitting on the floor. It can be explained by the heat conduction. Especially modified mean skin temperature was valued lower than the mean skin temperature in the case of lying on the floor at a higher floor temperature. The rectal temperature of the subject was stable at a temperature of about $37.5^{\circ} \mathrm{C}$. Minimal effects from the environment were found at the rectal temperature.

Fig. 5 shows the relation between globe temperature and mean skin temperature. The coefficient of correlation was higher valued between globe temperature and MST \& MSTd exceeded 0.9. The coefficient of correlation of modified mean skin temperature was slightly higher than the mean skin temperature in the case of lying on the floor, which can be explained by heat conduction.

\subsection{THERMAL SENSATION VOTE}

Fig. 4 shows the changes in thermal sensation votes with different postures at different air and water temperatures. When sitting on a chair the thermal sensation was affected by air temperature. In particular, the upper part was significantly affected by air temperature. The instep was lower than the temperature of the sole, when sitting on a chair. Based on the above, we have grounds for thinking that subjects wish for a higher air temperature. When sitting on the floor, all parts of the body was affected by the air and floor temperatures. When lying on the floor, the peripheral parts had lower temperatures at lower ambient temperatures. Especially, the feet were lower when lying on the floor. It can be assured that the feet was not in contact with the floor.

\subsection{GLOBE \\ TEMPERATURE AND \\ PSYCHOLOGICAL}

Fig. 6 shows the relation between globe temperature, thermal comfort and thermal sensation vote The thermal sensation votes were rated as slightly cool' or 'cool' at $\mathrm{Ta}=18^{\circ} \mathrm{C}$, and 'neutral' or 'slightly warm' at $\mathrm{Ta}=$ $23^{\circ} \mathrm{C}$ when sitting on a chair and sitting on the floor. When sitting on a chair, the thermal sensation vote was nearly the same for higher a lower floor temperature. When sitting on the floor, thermal sensation vote gradually changed with floor temperature at $\mathrm{Ta}=18^{\circ} \mathrm{C}$ in comparison with the case of $\mathrm{Ta}=23^{\circ} \mathrm{C}$ for which there were nearly no change. Thermal sensation was affected by air temperature rather than floor temperature. When lying on the floor the thermal sensation was dramatically affected by floor and air temperatures.

The comfort levels were rated as 'comfortable' at all conditions with air

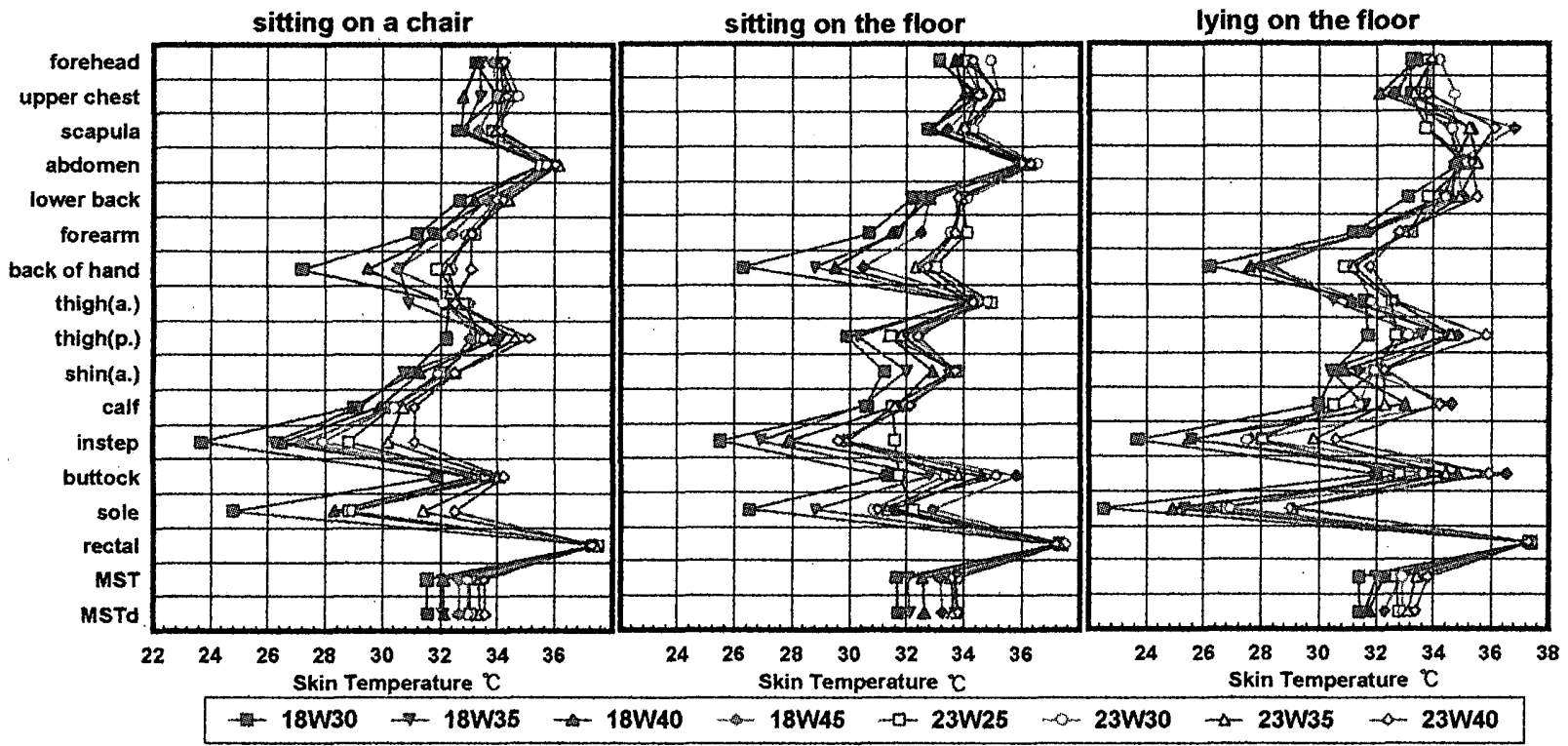

Fig. 3 Changes in Skin Temperature with Different Postures, Air and Floor Temperature
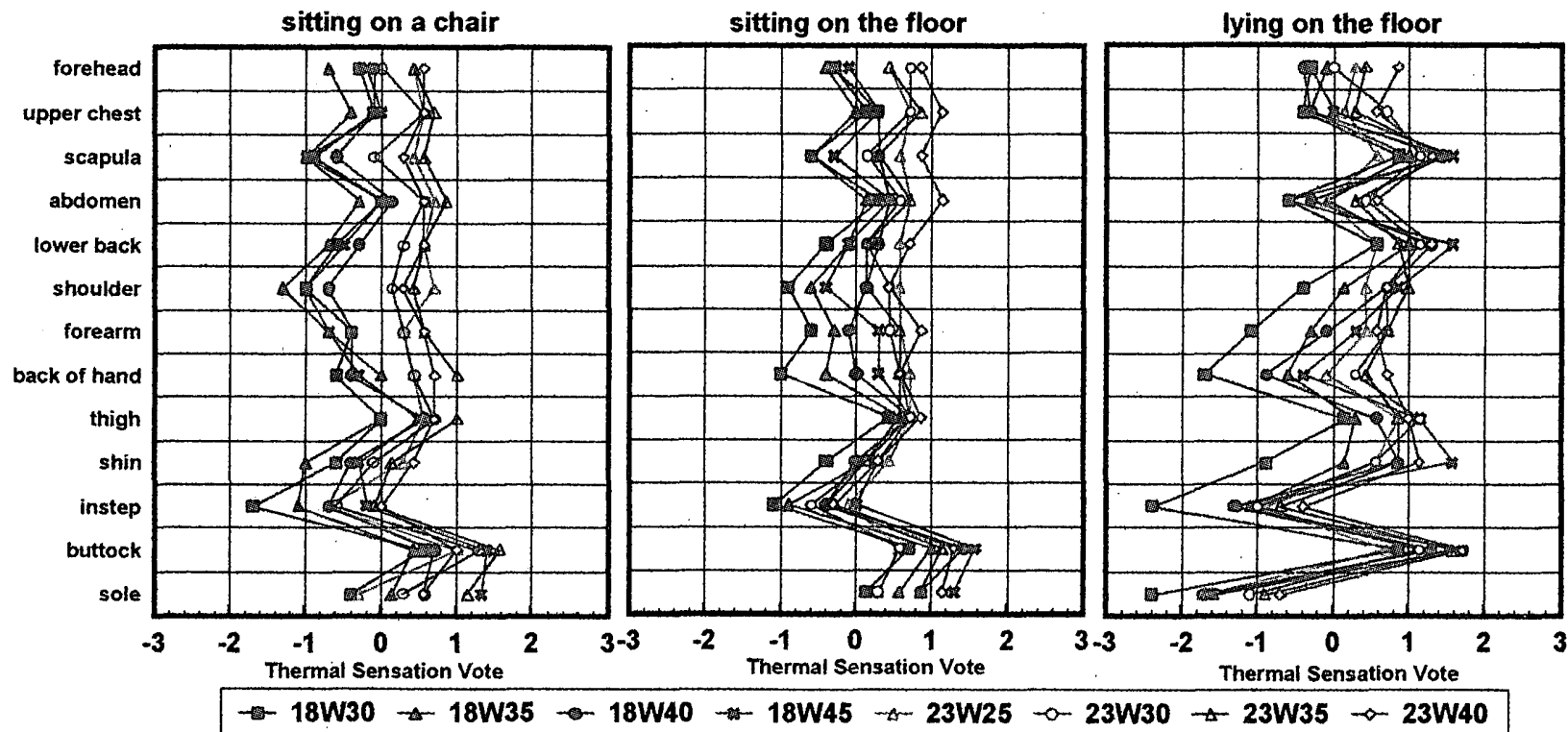

Fig. 4 Changes in Thermal Senation Vote at Different Postures, Air and Water Temperature 


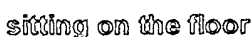

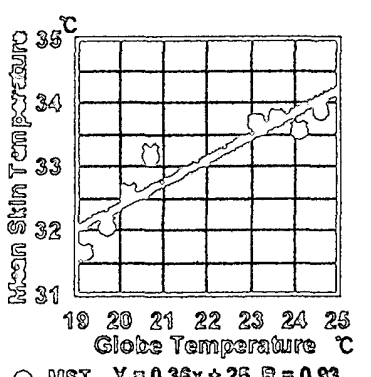

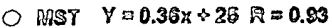

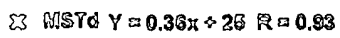

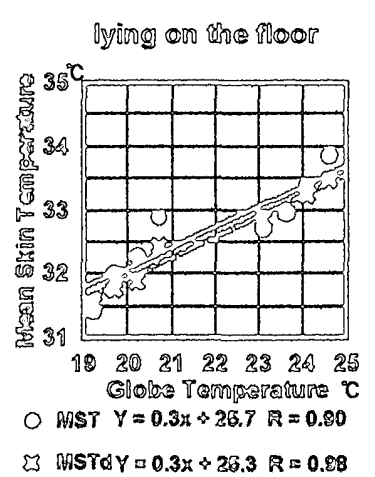

temperature $23^{\mathrm{C}} \mathrm{C}$. Uncomfortable condition is found at air temperature 18 $C$. Especially, when sitting on the floor levels of comfort were rated as highly comfortable at $\mathrm{Tw}=40^{\circ} \mathrm{C}$ and $45^{\circ} \mathrm{C}, \mathrm{Ta}=18^{\circ} \mathrm{C}$. When sitting on a chair, the thermal sensation was not much influenced by the floor temperature. When lying on the floor, the comfort level was rated as highly comfortable as the air and floor temperature increased. Judging from the above, it seems the subjects prefer a higher floor temperature at $\mathrm{T} a=18^{\circ} \mathrm{C}$. This experiment has shown that the floor temperature is an effective parameter in increseing the comfort level.

Fig. 7 shows the relation between globe temperature and preferred room temperature change. When sitting on a chair a $1-2^{\circ} \mathrm{C}$ higher air temperature was preferred at $\mathrm{Ta}=18^{\circ} \mathrm{C}$. When sitting on the floor the higher satisfacted at higher floor temperature by $\mathrm{Ta}=18^{\circ} \mathrm{C}$. When $\mathrm{Ta}=23^{\circ} \mathrm{C}$ was evaluated as comfortable' at all conditions. In general, when sitting on a chair thermal sensation was affected by air temperature and when lying on the floor it was also influenced by floor temperature.

Fig. 8 shows the relation between globe temperature and satisfaction with the floor temperature. Levels of satisfaction with the floor temperature was evaluated as 'satisfactory' at globe temperature above $20^{\circ} \mathrm{C}$ when sitting on a chair and sitting on the floor. Levels of satisfaction with the floor temperature were rated as 'satisfactory' at Tw $=35^{\circ} \mathrm{C}, 40^{\circ} \mathrm{C}$ and $45^{\circ} \mathrm{C}$ and $\mathrm{Ta}=18^{\circ} \mathrm{C}$ when lying on the floor. The recommended comfort level of floor temperature is found to be about $25^{\circ} \mathrm{C}$ with globe temperature $20^{\circ} \mathrm{C}$

Fig. 9 shows the relation between modified mean skin temperature, thermal sensation vote and thermal comfort vote. Thermal sensation was neutral at a mean skin temperature of $33^{\circ} \mathrm{C}$. The thermal comfort vote is obtained when the mean skin temperature is above $32^{\mathrm{C}} \mathrm{C}$ when sitting on a chair and sitting on the floor, and above $32.5^{\circ} \mathrm{C}$ when lying on the floor in this experiment.

3.6. MEAT LOSS

Fig. 10 shows the relation between globe temperature and total body heat loss, conductive heat loss.

The heat loss by conduction was affected by the floor temperature significantly when lying on the floor. when sitting on a chair, the conductive heat loss was not affected by the value of the conductive heat loss. The coefficient of correlation was higher valued between globe temperature and heat loss.

The difference of the heat loss by each postures, and the heat loss were effected by floor temperature and air temperature. Especially, in the case of lying on the floor was higher valued than another positions.

H. Relation Between Globe Temperânre,

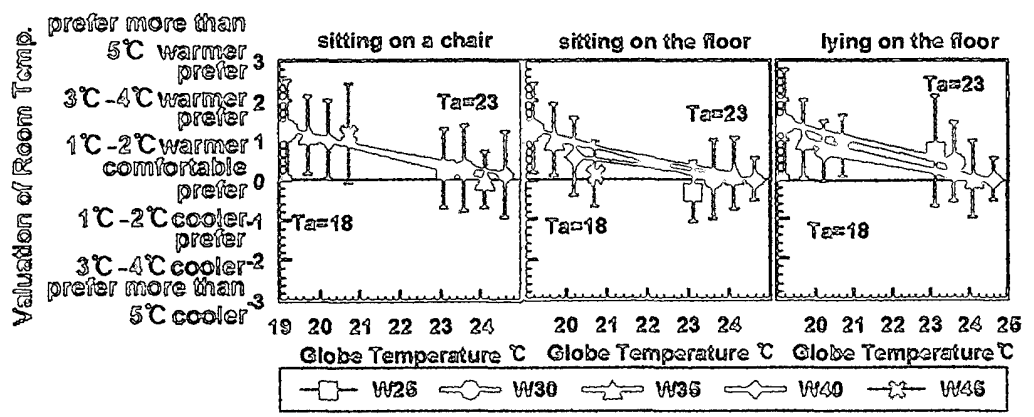

Fig. 7 Relation Berwesn Glor Temperature ano profersed Room Temperature Change

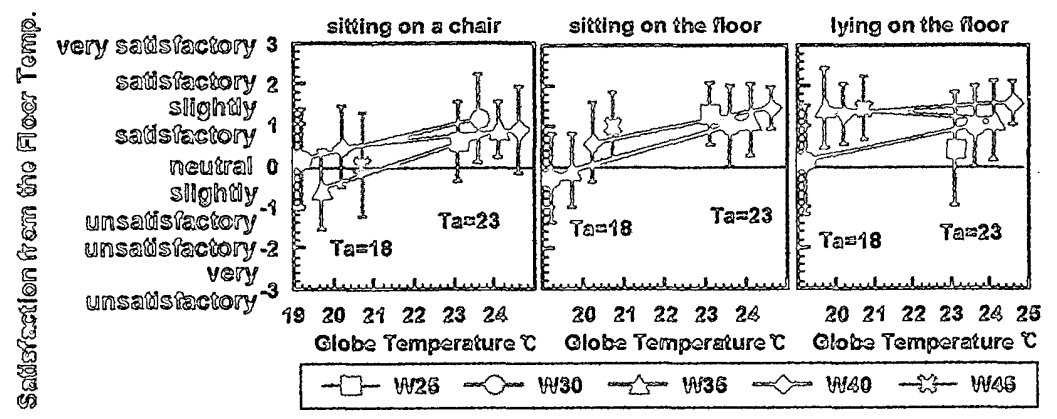

\section{CONCRUSBON}

These results lead to the following conclusions: (1) The skin temperature of body parts in contact with the floor was affected by the floor temperature. When sitting on the floor, the buttocks and soles of the feet were affected. When sitting on a chair only the soles of the feet were affected. When lying on the floor, the scapula,lower back, posterior thigh, calf, and buttocks were affected.

(2) The mean skin temperature ranged from $31.3^{\circ} \mathrm{C}$ to 33.8 C.

(3) The thermal sensation vote was neutral at a modified mean skin temperature of $33^{\circ} \mathrm{C}$.

(4) Levels of thermal comfort and satisfaction with the noor temperature was rated as 'satisfactory' at giobe temperature above $20^{\circ} \mathrm{C}$.

(5) The body parts in contact and the contact surface area between a floor and the human body were measured quantitatively.

(6) New weighting coefficients to calculate mean skin temperature are derived on the basis of Hardy \& DuBois formula.

(7) The correlation coefficient between globe temperature and mean skin temperature \& modified mean skin temperature exceeded 0.9

(8) The heat loss by conduction was significantly affected by the floor temperature when lying on the floor.

(9) The recommended permissible comfort level of floor temperature was about $25^{\circ} \mathrm{C}$ with globe temperature $20^{\circ} \mathrm{C}$.

Fig. (8) Relation Berwesn GHob Temperature and Sartisiaction with ithe Floor Tampararure 


\section{ACKNOWLEDGMENTS}

The author thanks Dr.S. MIYAMOTO, Nagoya Institute of Technology for his help and advice on measuring of contacted surface area and Dr. Bjarne W. OLESEN, D.F. Liedelt, VELTA, Germany for his valuable comments on the manuscript on this study.

\section{REFERENCES}

1. ASHRAE 55-1981, Thermal Environmental Conditions For Human Occupancy, ASHRAE , 1981

2. ASHRAE Handbook Fundamentals Chapter8, Physiological Principles And Thermal Comfort: p.8.19 P8.20,1993

3. 1SO-7730; Moderate Thermal Environments Determination of the PMV and PPD Indices and Specification of the Condition for Thermal Comfort, 1984

4. Nevins,R.G., Michaels, K.B. and Feyerherm, A.M.1964 :The effect of Floor Surface Temperature on Comfort ,Part 1, college age males, Part 2, college age females, ASHRAE Transactions, Vol.70, pp 29-43

Part 3,The elderly, 1966. ASHRAE Transactions, Vol.72, pp 292-300

5. Olesen, B.W.1997: Possibilities and Limitations of Radiant Floor Cooling, ASHRAE Transactions, Vol. 103, pp

6. Olesen, B.W.1977:Thermal comfort requirements for floors, Proceeding of commissions B1, B2, El of the IIR, Belgrade, pp 337-343, Thermal comfor requirements for floors occupied by people with bare feet, ASHRAE Transactions, Vol.83, Part 2, pp 41-57

7. Kim, B.A. et al. 1990: Influence of Floor Heating Temperature on the Human Body Seated on the Floor -in the case of electric floor heating system-J.Archit.Plann.Environ.Eng.,AIJ,No.417,pp 19-29, Nov.

8. CHOI,Y.S. et al. 1996:Combined Effect of Air and Heated Floor Temperature on Man in Japanese Sitting Posture,-J.Archit.Plann.Environ.Eng.,AIJ,No.480,pp714,Feb.

9. Hardy, J. D. and DuBois, E. F.1938: The Technic of Measuring Radiant \& Convection Journal of Nutrition, Vol. 15, No.5

10.Hanada, Y., Mihira, M. and Ohhata,K. 1981:Studies on the Thermal Resistance of Women's Underwear, Japan Res. Assn. Test. End-Uses., Vol.22 No.10, pp 31-41

11. Handbook of Physiological Science Vol.22. 1987, Physiology of Energy Exchange and Thermoregulation, Igaku-Shoin

12. Handbook of Physiological Science Vol.13. 1987. Physiology of Biological Rhythm, Igaku-Shoin

13. Kurazumu, Y. et al. 1999: The effects of conductive Heat Exchange for evaluation of the thermal environment on the human body,No.72,pp23-34,Jan.

14. MIYAMOTO S. et al. 1996: The effective radiation area and configuration factor for the person sitting on a floor, J.Archit.Plann.Environ.Eng.,AIJ,No. 479 pp2733,Jan

15. MIYAMOTO S. et al. 1999:Operative Temperature Considering The Effect of Heat Conduction Between A Heated Floor and The Person Sitting on it and InterReflection Radiation, J Archit Plann Environ. Eng AIJ,No. 515, pp57-62, Jan.

16. HIRAYAMA.K.1984: Influence of air and floor temperature upon the human body-in the case of clothed young male subjects in sedentary posture during summer and winter periods-,Summaries of Technical Papers of Annual meeting architectural Insrtitute of Japan, pp911-912, Oct.

17. Winslow, C.E.A. Herrington, L.P and Gagge, A.P.(1936)A new method of partitional calorimetry. Am. Joumal of physiology, Vol. 116, No. 3、 P.641-655

18. LEE,J.Y. et al. 1997:The Effect of Air and Heated Floor Temperature of System upon the Human Body - Partl. In the case of sitting on a chair and floor, and lying on one's back, Summaries of Technical Papers of Annual meeting architectural Institute of Japan, pp 817-818, Sep.

19. LEE, J.Y. et al. 1998: The Effect of Air and Heated Floor Temperature of System upon the Human Body - Part2. Study on accptable temperature with different expose the air, floor temperature, Summaries of Technical Papers of Annual meeting architectural Insrtitute of Japan, pp393-394, Sep.

20. LEE,J.Y. et al. :The Effects of Air and Floor Temperature of The Floor Heating System Upon The Human Body,Proceeding of The 8th International Conference,Vol.1,pp673-678, INDOOR AIR'99 Edinburgh, Scotland.

\section{[ANNEX1]}

This study calculated the weighting coefficients for calculation of mean skin temperature below equation. In order to calculate contacted surface area, it calculated the contacted area by substracting contacted area from seperated parts of body surface, and the value of uncontacted parts in relation to the opposite parts of the body surface area.

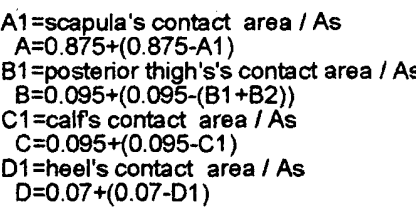

ting on a chair sltting on the floor lying on the floor

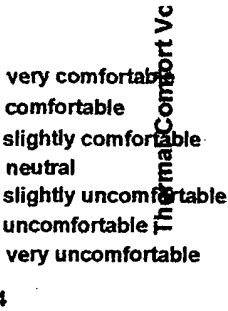

Modifled Mean Skin Temperature

- Thermal Comfort Thermal Sensation

\section{lation Between Modified Mean Skin Temperature and} Thermal Sensation Vote, Thermal Comfort Vote
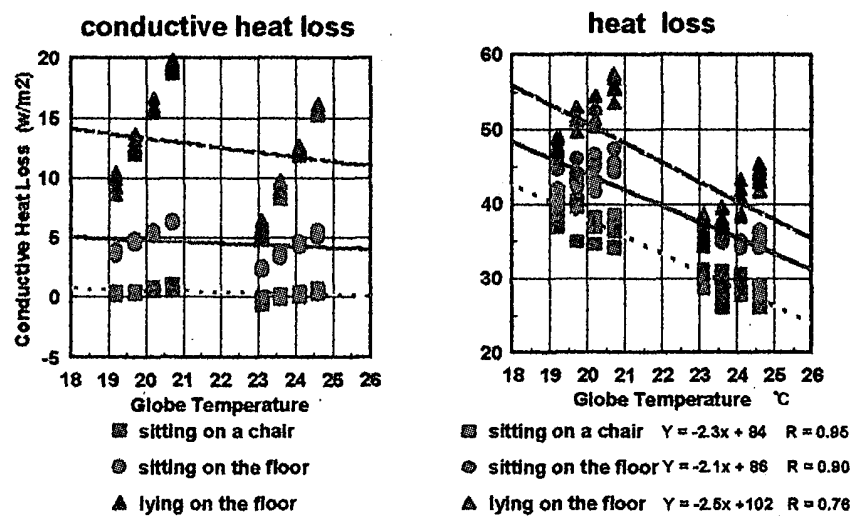

Fig. 10 Relation Between Globe Temperature and Heat Loss

[ANNEX2]

On this study, we calculated by HIRAYAMA's equation about Heat Loss. $M=C+R+C d \quad\left[W / m^{2}\right]$ - by hirayama's equation (1984)

In addition to the present paper calcurated by heat conduction from the contacted point skin temperature and water temperature of floor heating system.

$\mathrm{C}+\mathrm{R}=\mathrm{h}(\mathrm{Tsd}-\mathrm{To}) /\left(1+0.18 \mathrm{~h}^{*} \mathrm{lcto}\right)$

$\mathrm{Cd}=\lambda / l(\mathrm{Tw}-\mathrm{Tcs}) f$

$\mathrm{h}=\mathrm{hc}+\mathrm{hr}$

To= $(h r \operatorname{Tr}+h c T a) /(h r+h c)$

\section{[SYMBOLS]}

$M:$ rate of metabolic heat production [W/ $/ \mathrm{m}^{2}$ ]

C:convective heat loss $\left[\mathrm{W} / \mathrm{m}^{2}\right]$ R:radiative heat loss $\left[\mathrm{W} / \mathrm{m}^{2}\right]$

Cd:conductive heat loss $\left[\mathrm{W} / \mathrm{m}^{2}\right]$

hc.convective heat transfer coefic

hr:radiative heat transfer coefficient

(C) Ta:air temperature

Iclo: thermal resistance in clo units

1 floor material thickness [m]

$\lambda$ :flooring material heat transfer coefficient

Tw:water temperature of floor heating system

Tcs:contacted point skin temperature

$f$ : cont act $\theta d$ body surf ace ar $\theta \mathrm{a} /$ body suri ace ar $\theta a$

As: body surface area

[NOTES] A part of this study was presented at Annual Meeting Architectura Institute of Japan 97, 98 and INDOOR AIR'99 Edinburgh,Scotland. 


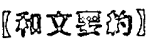

จ. 侪し゚的に

床暖房時の気温と床温の人体影響よび快適温度䉇围に関する研究 は多くの研究が見られるが、姿努の違いによる床接触部位に及ぼす 床温の影摿に関する研究は少ない。また、快適温度範囲の提案では かなり高い温度であり、実験室での気流の影響が含まれていること も考えられる。そこで、本研究では温水循環式床暖房を用いて、床 座、椅子座、仰卧の姿䇨の遗いによる生理的、心理的反応に及ほす 影留を把握する。また、床暖房の場合は伝尊による熱授受が存在す る環境であるため、伝導修正平均皮問温を考慮する必要があること 加伝導修正平均皮局温を求め、従来の平均皮府温と比較し、伝導 熱の影響を考虑する。さらに、人体影響を考罳した許容温度範囲を 気温と床温との関連で検討する。

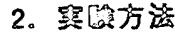

実験はFig. 1に示すように奈良女子大学人工気候室で、床暖房は 永循晎式床暖房装置を床に敷いて、冷温水循環装置から温水を流し た。設定条件はTable 1に示すように気温 $\left(18 、 23^{\circ} \mathrm{C}\right)$ と水温 (25、30、35、40、45C) の組み合わせで8条件、相対湿度は 40 $\%$ 、気流速度は $0.1 \mathrm{~m} / \mathrm{s}$ 以下とした。なお、前室は気温 $23^{\circ} \mathrm{C}$ 相対湿 度 $40 \%$ とし、笴子座安竫を保った。

床面との接触面積の測定は、挢明なアクリル板上の $100 \mathrm{~mm}$ の格子状 に $1 \mathrm{~mm}$ 幅のテープを貼り、その上に被駼者を位置させ、下方より写 真撮影を行った。像の歪みを確認したところ、誤差は約 $1 \%$ \%てっっ た。着衣は赛験時と同㥞な着衣で測定を行い、接触面が鮮明に写る ように、下着のように密着する薄手の計測着でも測定を行った。 Table 2に被験者の特徴を示す。温熱環境要索としては気温、黒球 温度、床温、相対湿度を測定し、赤外線放射温度計でも観測した。 人体反応として皮周温は皮佰表面 14 点を測定し、血圧・心拍效、体 重を実験前後に測定した。平均皮周温はHardy＆DuBoisの12点体 表面枚重み平均で算出し、尚、本研究では姿剜により床との接触面 穞が異なることで、本研究から求めた各姿势による伝導修正平均皮 周温算出法により計算した。心理反応としては温冷感、快適感など の申告を受けた。暴露姿倠はFig. 2に示した床座・椅子座・仰卧の 姿势で実験を行った。なお、被験者は青年女子7名とし、被験者の 特徴、着衣はTable. 3に示したとおりである。Table. 4に実験手順を 示す。被験者は前室に入室させ設定着衣を着用し、測定装置を取り 付け、筒子座安静を保ち、約 30 分後に人工気候空に入室し、設定条 件下に床座・椅子座は60分間、仰卧は椅子座の後に30分間翼露さ せた。Table. 5に本研究から求めた各姿势による伝導修正平均皮周 温の重みを示す。

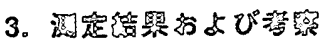

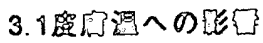

Fig.3に姿劳別・温度条件別の部位別皮閶温の平均分布を示す。全 体的に般幹部は高くなり、手部と足部の末梢部は低く、温度差も大 きくなる傾向が見られる。また、接触部位皮夙温は上昇する傾向が 見られる。筒子座の場合、椅子に接触している大腿後、筑部の皮周 温が高くなり、手背、足背、足底の圭梢部を除き分布は小さくな る。座座の場合は全体的に気温と床温の上䙹と共に皮堭温も徐々に 上界し、環境の影留を受けていることが分かる。手部、足部の抹消 部で皮府温の変動が大きく、大腿前の部位で高い皮底温を示してい るが、躯幹部と接近しているため、躯幹部からの影響であると考え られる。仰卧の場合は、床面に接触している部位で床温の影䋨を顕 著に受け、床からの伝導による影篦が考えられる。特に水温が $45^{\circ} \mathrm{C}$ の場合は臂部の皮蔺温で約 $36^{\circ} \mathrm{C}$ とかり高い皮用温となっている。 全体の平均皮周温は $31.3^{\circ} \mathrm{C} \sim 33.8^{\circ} \mathrm{C}$ の範囲にある。直腸温はほほ 37.5 Cにあり、環境の影響がほとんど見られない。伝導修正平均皮 用温は床座の場合は平均皮局温よりも高い值を示し、接触伝尊によ る影響を示すことが出来た。しかし、仰臥の姿枩の場合は床温が高
い場合、従来の平均皮周温よりもやや低い温度を示している。Fig.5 に黑球温度と平均皮周温との關係を示す。黑球温度と平均皮夙温、 伝禉修正平均皮墽温とも0.9以上の高い相関が得られた。特に、仰

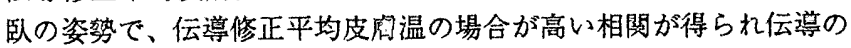
影搖をより受けていることと考えられる。

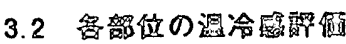

Fig.4に姿势別・温度条件別の部位別温冷感の平均分布を示す。椅 子座の場合は、躯幹部で気温の影響が大きく見られ、仰卧の姿浊の 場合は末梢部で、低い環境で低い温冷感評価が得られた。特に、足 部は床に接触してないため、低い評価を示した。

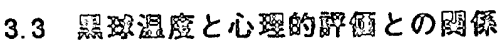

Fig. 6に黑球温度と全身温冷感および快適感申告の関係を示す。 全身温冷感申告で椅子座、座座の場合は気温が18Cの場合「やや涼 しい」「涼しい」の評価を示し、気温 $23^{\circ}$ では「どちらとも言えな い」「队暖かい」の申告となっている。仰卧の申告の場合は気温 と床温の影響が顕著にみられ、床温が高くなることによって申告の 評価も暖かい側の評価となる。また、気温 $18^{\circ}$ 床温 $22.5^{\circ} \mathrm{C}$ の場合に 寒い㒋の評価を示し、仰臥の姿势の場合はある程度高い床温が望ま しいと考えられる。快適感申告では気温 23 Cの場合には全条件で快 適側の評価となっている。気温 $18^{\circ} \mathrm{C}$ 場合にはグローブ温度 $20^{\circ} \mathrm{C}$ で快適側の申告となる。

Fig.7にグローブ温度と室温評価との関係を示す。椅子座の場合

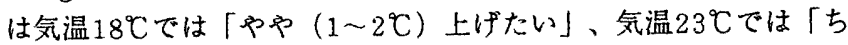
ようど良いと評価されている。これに対し、床座の場合は気温が 18 Cでは床温が高いはど「ちょうど良い」側の評価となり、床温が 高いと低い気温でもある程度快適な環境を創り出せることを示して いると考えられる。気温 23 Cではほとんど「ちょうど良い」側の評 価である。

Fig. 8に黒球温度と床温の满足感申告との閧係を示す。椅子座、 床座の場合はグローブ温度 $20^{\circ} \mathrm{C}$ 以上で床温に対して満足側の評価と なっている。仰臥の場合は全条件の平均值で床温に対して满足して いる。

Fig.9に平均皮周温と全身温冷感・快適感との関係を示す。平均 皮问温は約 $33^{\circ}$ Cで温熱的中性の「どちらとも言えない」の評価とな

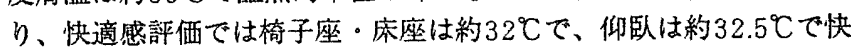
適側の評価となっている。

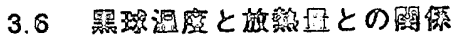

Fig.10にクローブ温度と放熟量との関係を示す。

仰臥の姿缸の場合、伝導による放熱量は床温の影響を顕著に受けて いる。椅子座の場合は伝導による影響はほとんど受けていない。グ ローブ温度と放熱量の場合、高い相関が得られた。

Q. 到と的

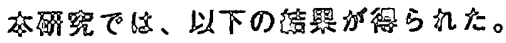
(1)床接触部位は床温の影瑤を大きく受け、床座の場合は「漓部」と 「足部」、椅子座の場合は「足部」のみ、仰卧の場合は「背中」、

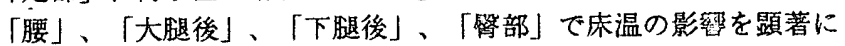
受けていた。(2)平均皮周温は約 $31.3^{\circ} \mathrm{C} \sim 33.8^{\circ} \mathrm{C}$ の簕囲にあった。(3) 平均皮夙温的 $33^{\circ}$ Cで温熱的中性評価となっていた。(4)ダローブ温度 20 Cで快適感、床温に対して満足という評価が得られた。(5)本研究 では、各姿势の床面と人体の床接触面積を求めた。(6)既往のHardy \& DuBoisの平均皮府温算出法を修正した伝導修正平均皮问温を求め た。(7)黑球温度と平均皮周温、伝導修正平均皮用温との間に0.9以 上の高い相関が得られた。(8)仰臥の姿荌の場合、伝導による放熱量 は床温の影響を顕著に受けていた。(9)本研究では床暖房の許容範囲 として、グローブ温度 20 、床温 $25^{\circ}$ 提案する。

（1999年12月10日原稿受理，2000年 5 月 12 日採用決定） 